\title{
Quality of Broiler Meat That Is Given Sorgum As A Corn Replacement
}

\author{
Ni Made Yudiastari ${ }^{1}$, Luh Suariani ${ }^{2}$, Ni Ketut Etty Suwitari ${ }^{3}$, I Nyoman Kaca ${ }^{4}$, Yan Tonga ${ }^{5}$ \\ yudi.astari@yahoo.co.id ${ }^{1}$
}

\begin{abstract}
Animal Husbandry Department, Agriculture of Faculty, Warmadewa University
\end{abstract}
\begin{abstract}
The use of sorghum seeds in the ration is supplementary (substitution) to corn because the nutritional content of sorghum seeds is no different from corn, namely sorghum protein content of $9.50 \%$ while corn is $9 \%$ but tannin content in corn is quite high $(0.40$ $3.00 \%$ ) so that it can only be used in limited quantities because it can affect the function of amino acids and proteins. In addition, tannins can affect the metabolism of carbohydrates by binding to starch, consequently it is difficult to digest by the amylase enzyme, causing the production of energy or body fat to decrease. At the present time the quality of meat gets the attention of consumers, especially in Bali which is a tourism area with culinary that is very favored so it needs good quality meat. For that reason, the purpose of conducting this research is to find out how much percentage of sorghum can be given in broiler chicken rations to get better carcass / meat quality. This study was conducted using a completely randomized design (CRD) with treatment and 3 replications consisting of P0 (control ration without the addition of sorghum flour), P1 (ration containing 7\% sorghum), P2 (ration containing 14\% sorghum), P3 (ration containing 21\% sorghum) and P4 (ration containing $28 \%$ sorghum). The variables measured were chicken meat, cooking implants, water binding capacity, $\mathrm{pH}$, meat fat content and total microbial content of broiler chicken meat aged 6 weeks. The results showed that the replacement of some corn with sorghum had a significant effect on water content, water holding capacity, cooking shrinkage and fat content of broiler meat aged 6 weeks but did not have a significant effect on $\mathrm{pH}$ and total microbial content (TPC). The conclusion that can be drawn is that the substitution of corn with sourgum to the level of P3 $(21 \%)$ significantly $(\mathrm{P}<0.05)$ can reduce the binding capacity of water, cooking losses and fat content of broilers aged 6 weeks, but have an unreal effect $(\mathrm{P}>0.05)$ against $\mathrm{pH}$ and total microbial meat of broiler chicken aged 6 weeks.
\end{abstract}

Keywords: Broiler, Sorghum, Physical and Chemical Quality

\section{Introduction}

Broiler farms have developed well in Indonesia, but have problems, namely frequent price fluctuations, especially ration prices, which creates instability in the poultry industry. The high price of commercial feed is due to the fact that most poultry feed ingredients are still imported. [1] states that rations play an important role in the success of broiler farms, because the costs incurred for rations can reach $70 \%$ of the total production costs. Therefore, it needs to be 
sought to find alternative but inexpensive quality feed ingredients. One that can be used is sorghum.

Sorghum seeds is a choice that can be used because besides the price is cheaper than corn, the nutritional content is equivalent to corn. In Broiler ration, the use of corn as the most dominant energy source is more than $50 \%$ as an import commodity, the price of corn is very vulnerable to fluctuations in the rupiah exchange rate and international raw material prices, thus narrowing the opportunity to get cheap rations. The use of sorghum seeds in animal feed rations is supplementary (substitution) to corn, but because of the high tannin content (0.40-3.60\%), sorghum seeds can only be used in limited quantities because it can affect the function of amino acids and proteins. According to Scott et.al (1976) in [2] the tannin content in rations above $0.50 \%$ can suppress chicken growth and if it reaches $2 \%$ it will cause death [3]. But [4] said that the use of sorghum $30-80 \%$ in rations did not affect chicken performance. According to [4] and ICRISAT (1994) in [5] sorghum can replace all corn in feed rations of chickens, ducks, goats, pigs and cattle without causing side effects.

Tanin is one of the anti-nutrients found in many food ingredients such as sorghum, beans, tea, apples, grapes and other kinds of fruit [6]. Tanin also affects carbohydrate metabolism by binding to starch so that it is difficult to digest by the amylase enzyme. [7] says the effect of binding tannins on starch in pigs causes less digestible starch so that energy or fat production decreases resulting in thinning of back fat in other words improving quality the pork meat. In Indonesia chicken carcass quality standards are regulated in SNI 3924: 2009 [8].In this standard set classification, quality requirements, carcass pieces, packaging, labeling, and storage of carcass and chicken meat. Carcass quality requirements begin with physical carcass and microbiological assessment of chicken carcasses. This is very important because in the current era where the world of tourism is growing rapidly, it takes good quality chicken meat.

In developed countries, consumers are very concerned about the quality of meat to be consumed, automatically better-quality meat will have a higher price. Especially now that high levels of cholesterol and LDL fat are the main risk factors for coronary heart disease.

From the description above, researchers are interested in conducting research on replacing a portion of corn with sorghum in rations on the quality of broiler chicken meat.

\subsection{Formulation of the Problem.}

From the situation above, the problem can be formulated, namely how to replace corn with sorghum, will it affect the quality of broiler chicken meat?

\subsection{Research Purposes}

The purpose of this study is to find out what percentage of sorghum can be given in poultry rations to get better carcass quality.

\subsection{Urgency of Research}

In the livestock business the obstacle that is often faced is the high price of feed which often causes losses to farmers. This is due to the fact that many feed ingredients are imported, so prices are high. While the cost of feed can reach 60-70 of production costs. Therefore, it is 
necessary to find alternative feed ingredients that are cheap but can still increase meat production. Alternatives that can be used as corn substitutes or as substitutes for corn are sorghum. Because we know the most dominant use of corn is $\pm 50 \%$ in poultry rations, while corn is still imported.

The use of sorghum seeds in livestock rations is supplementary (substitution) to corn because the nutritional value is not different from corn. Sorghum seeds can be given directly in the form of seeds or processed first and mixed with other feed ingredients. In addition, sorghum seeds contain tannins which are quite high (0.40-3.60\%) so they are used limited in rations because they can affect the functions of amino acids and proteins. To get good carcass quality, it is necessary to know what percentage of the right content can be given in the ration to increase the production and quality of broiler chicken carcassesn order to support the tourism industry which is growing rapidly, it takes good quality and quality of chicken meat. Quality requirements starting from the physical assessment of carcass to its microbiological content. Which in good meat requires a lowfat content. To produce dagung with a low fat content, a treatment is needed on the feed. Therefore we tried to replace corn with sorghum in broiler rations aged $0-6$ weeks.

\section{Research Methodology}

\subsection{Location and Duration of Research}

Research on maintenance of broiler chickens was carried out on Jalan Sedap Malam while the quality of chicken meat was carried out at the Basic Science Laboratory of the Faculty of Agriculture, Warmadewa University and cholesterol levels were carried out at the Analytical Chemistry Laboratory of Udayana University, Denpasar. Maintenance of broiler is carried out for 3 months.

Table 1. The composition of ingredients for ration treated broiler chickens aged 2-6 weeks

\begin{tabular}{|c|c|c|c|c|c|}
\hline \multirow[t]{2}{*}{ Name of material } & \multicolumn{5}{|c|}{ Treatment Ration } \\
\hline & R0 & $\mathrm{R} 1$ & $\mathrm{R} 2$ & R3 & $\mathrm{R} 4$ \\
\hline Corn $(\%)$ & 58 & 51 & 44 & 37 & 30 \\
\hline Sorghum (\%) & 0 & 7 & 14 & 21 & 28 \\
\hline Rice Bran (\%) & 12 & 12 & 12 & 12 & 12 \\
\hline Fish meal $(\%)$ & 12,5 & 12,5 & 12,5 & 12,5 & 12,5 \\
\hline Soybean Meal (\%) & 15 & 15 & 15 & 15 & 15 \\
\hline Coconut oil & 1,5 & 1,5 & 1,5 & 1,5 & 1,5 \\
\hline Mineral & 1 & 1 & 1 & 1 & 1 \\
\hline Total & 100 & 100 & 100 & 100 & 100 \\
\hline
\end{tabular}

Source: Based on calculations by Scott et al. (1982)

Information:

$\mathrm{P} 0=$ Control ration without addition of sorghum flour

$\mathrm{P} 1=\mathrm{A}$ ration containing $7 \%$ sorghum flour

$\mathrm{P} 2=\mathrm{A}$ ration containing $14 \%$ sorghum flour

P3 = Ration containing 21\% sorghum flour

$\mathrm{P} 4=\mathrm{A}$ ration containing $28 \%$ sorghum flour 


\subsection{Research Methods}

The study was carried out with a completely randomized design method (CRD) with 5 (five) treatments and 3 (three) replications. The treatment is as follows: P0 (chicken meat that is not given sorghum), P1 (chicken meat given ration containing 7\% sorghum), P2 (chicken meat given ration containing $14 \%$ sorghum), P3 (chicken meat given ration containing $21 \%$ sorghum) and $\mathrm{P} 4$ (chicken meat given rations containing $28 \%$ sorghum).

The rations used in this study were rations mixed with sorghum, milled corn, bran, soybean meal, fish meal, minerals and coconut oil. Rations and drinking water are given by adlibitum. The composition of feed ingredients and feed ingredients composition ration treatment broiler chickens aged 2-6 weeks can be seen in Tables 1 and 2 .

\subsection{Variables Observed}

The variables observed in this study are as follows $\mathrm{pH}$, cooking shrinkage value, water binding capacity, total moisture content, microbial total (TPC) analysis and fat content.

Table 2. The composition of food substances broiler ration treatment aged 2-6 weeks

\begin{tabular}{lllllll}
\hline \multirow{2}{*}{ Material } & \multicolumn{2}{l}{ Ration } & & \multicolumn{2}{l}{$\begin{array}{l}\text { Standar } \\
\text { Scoot1982 }\end{array}$} \\
\cline { 2 - 5 } & $\mathrm{R} 0$ & $\mathrm{R} 1$ & $\mathrm{R} 2$ & $\mathrm{R} 3$ & $\mathrm{R} 4$ & $20-22 \%$ \\
Crude Protein (\%) & 19,253 & 19,321 & 19,449 & 19,547 & 19,645 & $5,50 \%$ \\
Crude Fiber (\%) & 3,625 & 3,625 & 3,625 & 3,625 & 3,625 & 3200 \\
EM (Kkal/kg) & 2985,2 & $2,976,8$ & 2968,4 & 2960 & 2951,6 & $2-7 \%$ \\
Fat (\%) & 5,585 & 5,505 & 5,428 & 5,351 & 5,274 & $0,9-1,2 \%$ \\
Ca (\%) & 0,7615 & 0,7622 & 0,7629 & 0,7636 & 0,7643 & $0,7-1,0 \%$ \\
P & 0,8045 & 0,8045 & 0,8045 & 0,8045 & 0,8045 & 0
\end{tabular}

Source: NRC (1994) and Scott et.al (1982)

\subsection{Statistic Analysis}

Data obtained from the results of the study analyzed variance, if there were results that were significantly different $(\mathrm{P}<0.05)$ between treatments then a multiple distance test was performed from Duncan [9].

\section{Results and Discussions}

The average effect of replacing a portion of corn with sorghum on the physical and chemical quality of 6 weeks old broiler meat is as presented in Table 1 .

Table 1. The effect of replacing a portion of corn with sorghum on the quality of broiler aged 6 weeks

\begin{tabular}{|l|l|l|l|l|l|l|}
\hline \multirow{2}{*}{ Variable } & \multicolumn{4}{|l|}{ treatment } & Rataan \\
\cline { 2 - 6 } & P0 & P1 & P2 & P3 & P4 & \\
\hline $\mathrm{pH}$ & $6,12 \mathrm{a}$ & $6.08 \mathrm{a}$ & $6.05 \mathrm{a}$ & $6.00 \mathrm{a}$ & $6,14 \mathrm{a}$ & 6,08 \\
\hline $\begin{array}{l}\text { Meat Water } \\
\text { Content (\%) }\end{array}$ & $75,57 \mathrm{a}$ & $74,97 \mathrm{a}$ & $74,34 \mathrm{~b}$ & $73,81 \mathrm{bc}$ & $72.08 \mathrm{c}$ & 74,16 \\
\hline Cooking & $18,37 \mathrm{a}$ & $17,04 \mathrm{a}$ & $16,64 \mathrm{~b}$ & $16,24 \mathrm{bc}$ & $15,97 \mathrm{c}$ & 16,85 \\
\hline
\end{tabular}




\begin{tabular}{|l|l|l|l|l|l|l|}
\hline losses & & & & & & \\
\hline $\begin{array}{l}\text { Water } \\
\text { Bonding }\end{array}$ & $21,19 \mathrm{a}$ & $18,89 \mathrm{a}$ & $18,49 \mathrm{a}$ & $17,84 \mathrm{~b}$ & $17,65 \mathrm{c}$ & 18,81 \\
\hline TPC(CFU/g) & $3 \times 10^{3}$ & $3,1 \times 10^{3}$ & $3,63 \times 10^{3}$ & $3,93 \times 10^{3}$ & $3,93 \times 10^{3}$ & $3,52 \times 10^{3}$ \\
\hline $\begin{array}{l}\text { Meat Fat } \\
\text { Content (\%) }\end{array}$ & $1,43 \mathrm{a}$ & $1,39 \mathrm{a}$ & $1,34 \mathrm{~b}$ & $1,33 \mathrm{bc}$ & $1,30 \mathrm{c}$ & 1,35 \\
\hline
\end{tabular}

Notes: Different letters towards the line show significantly different.

The quality of chicken meat is influenced by several factors, both when animals are still alive and after being cut. At the time of live cattle, the determinants of meat quality are maintenance methods, including feeding, maintenance, and health care, while after animals are cut the quality of meat is affected by bleeding when animals are cut and microbial contamination. Chicken meat must meet the microbiological quality set by SNI 3924 (2009)[8] with a maximum microbial contamination threshold of $106 \mathrm{CFU} / \mathrm{g}$ and negative Salmonella sp.

\section{1. $\mathrm{pH}$}

The effect of treatment on the $\mathrm{pH}$ of 6 weeks old chicken meat showed results that were not significantly different. The $\mathrm{pH}$ of chicken meat obtained ranges from 6.00 to 6.14. PH values and aw are important indicators in assessing the physical quality of meat. Both of these indicators are closely related to the presence of microbes in meat so that it determines the level of durability and quality. The $\mathrm{pH}$ obtained is still in the normal range. $\mathrm{pH}$ of meat in the opinion of [10], namely 5.96-6.07 and the results of [18] where the $\mathrm{pH}$ of broiler chicken meat without any treatment is 6.11-6.25. However, the results of this study are still lower than the results of the study of [11], where broiler chicken meat without any treatment has an average $\mathrm{pH}$ of 6.79 in the shelf life of 6 - 12 hours.

This is supported by the opinion of [12] stated that what determines the final $\mathrm{pH}$ of meat is the size of the glycogen content in the muscle when cutting. The research conducted showed that the $\mathrm{pH}$ value of broiler chicken fed with the addition of pulp of virgin coconut oil (VCO) above the level of $1 \%$ differed significantly $(\mathrm{P}>0.01)$ from 6.11 to 6.25 the $\mathrm{pH}$ value of broiler chicken meat. The difference in $\mathrm{pH}$ value due to the addition of VCO pulp in feed is thought to affect the levels of broiler muscle glycogen which can affect the $\mathrm{pH}$ value of meat [13]

[14] stated that if animals move too much before cutting, the supply of muscle glycogen will decrease, because some glycogen is used for motion. In this case the livestock do a lot of motion activities so that the glycogen reserves in the meat muscle are small. As a result of low lactic acid production, the $\mathrm{pH}$ of the meat will slowly rise. The $\mathrm{pH}$ of fresh meat depends on the content of muscle glycogen when cutting. The difference in binding capacity of meat between each individual animal on the same species is usually related to muscle $\mathrm{pH}$. WHC will increase if $\mathrm{pH}$ increases.

Many factors can affect the $\mathrm{pH}$ of meat as suggested by [15]. Stress before cutting, such as climate, aggressive behavior among cattle or excessive movement also has a large influence on the growth or depletion of muscle glycogen and will produce dark meat with High $\mathrm{pH}$ (greater than 5.9). The $\mathrm{pH}$ value of this meat needs to be known because the $\mathrm{pH}$ of the meat will determine the growth and development of bacteria. Almost all bacteria grow optimally at a $\mathrm{pH}$ of about 7 and 
will not grow just below $\mathrm{pH} 4$ and above 9, but optimal growth is determined by the stimulant work of various other variables beyond the acidity factor itself [16]

\subsection{Water Power}

In this study it was found that the higher the level of administration of sorghum will reduce the richness of water in broiler chicken aged 6 weeks. The highest water content obtained in the treatment without giving sorghum is equal to 21.19 while the lowest is obtained by giving sorghum $28 \%$ (P4) which is 17.65 and statistically significantly different $(\mathrm{P}<0.05)$.

[17], states that the binding capacity of meat depends on the number of reactive groups of protein. A low $\mathrm{pH}$ due to the large amount of lactic acid, the reactive group of protein will cause a lot of meat water to be released. In addition, according to parameters that can be used to see the moisture level of meat, moist meat indicates that the binding power of the meat to water is quite high, while the meat that is rather dry indicates that the binding power of the meat has decreased. This is usually marked by the appearance of a rather blackish flesh color (DFD meat).

This will also be seen in the amount of liquid that comes out (drip) at the time the book's meat is thawaing. The higher the liquid that comes out of the meat shows that the value of the binding power of water by the meat protein is getting lower [13]. A decrease in the value of the binding power of water can also increase the value of cooking losses [18]. The binding capacity of water is the ability of meat to bind the water added as long as there is an influence of external forces, such as meat cutting, heating, grinding and pressure. Water in the meat muscle consists of three layers, namely the water layer is chemically tightly bound by meat protein which is hardly affected by relatively large mechanical or physical strength [15]. Decreasing the binding capacity of water can be known by the presence of fluid called weep on uncooked raw meat or drip on frozen raw meat that is refreshed or wrinkled in cooked meat [15] Water joining is influenced by many factors including species, age, muscle function, $\mathrm{pH}$, intramuscular fat, nutrients, stress and processing. Changes in the value of the binding capacity of water during the process are also determined by the micro level of the network structure, the structure of the protein responsible for the binding of water and determining the amount of free water in the meat [16].

\subsection{Cooking Shrinkage}

The effect of treatment on the cooking shrinkage value of 6 weeks old broiler chicken fed rations containing sorghum instead of corn decreased with increasing levels of sorghum administration. The highest cooking loss was 18.37 in the treatment without sorghum and significantly decreased to the lowest of 15, 97 in treatment P4 (28\% of sorghum). The cooking shrinkage value is the value of the meat mass which decreases after the heating process or cooking process. This cooking shrinkage value is closely related to the binding power of water. The higher the power binding the water, then when the process of heating water and liquid nutrients will be a little out or wasted so that the mass of meat is reduced even slightly. According to [19] meat that has a low cooking shrinkage rate, has good quality because of the possible release of meat nutrition during cooking is also low. Frozen meat or stored in cold temperatures tend to experience changes in muscle protein, which results in reduced value of binding capacity of muscle protein water and increased amount of fluid that comes out (drip) from meat [20]. 


\subsection{Meat Water Content}

In this study the treated water content of broiler chicken meat was obtained between 75.57 - 72.08. Meat water content decreases with increasing levels of sorghum administration. According to [13], broiler meat water content is $68-75 \%$. Broiler meat contains $21 \%$ protein, $19 \%$ fat, and mineral substances $3.2 \%$. Winarno et al. (1980) stated that the surface water content of food is influenced by the humidity around it (RH). If the water content of food is low while RH is high, there will be absorption of moisture from the air so that the food becomes moist or the water content becomes higher. If the food temperature is lower (cold) than at all there will be condensation of air vapor on the surface of food, the occurrence of this condensation does not always come from outside food, some food can produce water from respiration and transpiration so that it increases the water content of food, this water which can help microbial growth.

The water content after the livestock is cut depends on the high and low $\mathrm{pH}$ value [21] Fresh meat feels wet when touched. This is due to the water content in the meat [22]. This glycolysis process will produce lactic acid which causes a decrease in the $\mathrm{pH}$ of the meat.

According to [21\} water is the largest composition of meat. Water content in the meat will decrease as a decrease in $\mathrm{pH}$, because water content is one of the factors that cause high and low $\mathrm{pH}$. This is related to hydrogen ions which bind to one another in meat. The occurrence of the process of glycolysis in meat combined with oxygen will release $\mathrm{H}$ atoms and will form water. Water content is also influenced by the difference in concentration of solvents and solutes better known as the osmosis process. [23] states that the osmosis process is a process of diffusion of water through a differential permeable membrane from a low concentration place to a high concentration site.

\subsection{Meat Fat Levels}

Fat levels of broiler chicken meat at 6 weeks of age significantly decreased $(\mathrm{P}, .005)$ along with the increasing level of sorghum administration. The highest fat content was obtained in treatment P0 (without sorghum) which was equal to $1.43 \%$ and the lowest was obtained in treatment P4 (28\% sorghum) which was equal to $1.30 \%$. Decrease in fat content of meat is closely related to the tannin content found in sorghum. Tanin is a compound with a high molecular weight containing hydroxyl and several components such as carboxyl which is capable of binding complexes to proteins and several other macromineral conditions in the environment. Tanin has the ability to form complex bonds with protein, starch, cellulose and minerals. Tanin can affect the value of nutrients contained in food and feed consumed by animals in legumes, grass and fruit that are not yet ripe. Tanin causes a feeling of shrinking on the tongue because it is able to bind to salivary fluid in the mouth [24] Meat protein content is closely related to feed with sufficient nutritional value and a good digestive system. According to [25] overall meat fat in raw chicken conditions on average $2.1 \%$. [26] which states that, there are significant differences in the fat content of 7-week-old meat between roosters (2.68\%) and hens (2.86\%).

\subsection{Total Microbes}

The total microbial or total plate count (TPC) obtained in this study ranged from 3 - 3.9 x103. Total microbes based on SNI 01-2897-2008 is a method of calculating the total microbes contained in a product that grows on agar media at the specified temperature and incubation time. 
Microbes that grow in the agar media are calculated by the colon without using a microscope. The test results are stated by CFU (Colony Forming Unit) per ml. This means that in all treatments the total microbes are below the standard.

Food such as chicken meat can act as a substrate for the growth and proliferation of pathogenic microbial species that can cause disease for humans who eat it. Anything that can be directly or indirectly in contact with meat can be a source of contaminants. This contamination can be overcome or reduced by carrying out hygienic handling with the best sanitation system. The amount of microorganism contamination in meat will determine the quality and shelf life of meat processes [26] The factors that affect the growth of microorganisms in meat are of two kinds, namely (a). Intrinsic factors include the nutritional value of meat, the state of water, $\mathrm{pH}$, the potential for oxidation-reduction and the presence or absence of a barrier or inhibitor substance; (b). Extrinsic factors, such as temperature, relative humidity, the presence or absence of oxygen and the shape or condition of meat [27] Precise measurement of the number of microorganisms in chicken meat is an important basis to do. This is done so that microorganisms that can grow on chicken meat do not exceed the maximum limit of microbial contamination.

\section{Conclusion}

The results showed that the partial replacement of rations with sorghum was $14 \%$ significantly $(\mathrm{P}<0.05)$ able to reduce meat water content, cooking shrinkage of meat and fat content of meat. Replacement of corn with sorghum did not have a significant effect $(\mathrm{P}>0.05)$ on $\mathrm{pH}$ and TPC of broiler chicken aged 6 weeks. Karkasa and chicken meat produced in this study in all levels of sorghum replacement still meet quality standards in accordance with the SNI 3924: 2009 normative reference.

\section{References}

[1] Daghir, N.: Poultry Production in Hot Climate (2nd Ed.). UK: University Press Cambridge (1998)

[2] Koentjoko.: Sorgum untuk makanan ternak Unggas. Risalah Simposium Prospek Tanaman Sorgum untuk Pengembangan Agroindustri, 17 - 18 Januari 1995. Edisi Khusus Balai penelitian Tanaman Kacang kacang dan Umbi umbian. No, 4-1996:," pp. 213-216 (1996)

[3] F. H. K, Rayudu. G.V.N., R.Cadirvel. Vohra, P.: Toxcity of tannicacid and its metabolits of chickens, Poult. Sci, vol. 49 (1970)

[4] Beti, S. Y.A., A. Ispandi.: Sorgum Monografi, No 5. Balai Penelitian Tanaman Pangan, Malang (1990)

[5] B. V. S. J. W. S. and Reddy, H. F. W. R.: Sorgum Rain Quality Improvement For Food, Feed and Industrial Uses. Edisi khusus Balai Penelitian Tanaman Kacang-kacangan dan Umbi-Umbian. No. 4, pp. 32-52 (1995)

[6] Liener, I.: Toxic Constituents of Plant Foodstuffs. New York: Food Science and Technology Academic Press Inc (2001)

[7] Tandi.: Penggunaan Biji Pohon tahan Api (macadamia hildebransi) dalam Pakan Ternak babi Ditinjau dari Kandungan Taninnya. Disertasi Program pascsarjana (KPK) Institur Pertanian Bogor dan Universitas Hasanudin (1993)

[8] (BSN) Badan Standarisasi Nasional, SNI 01-3924-2009 tentang Mutu dan Karkas Daging Ayam. Jakarta (ID): BSN (2009)

[9] T. J. Stell GD, Prinsip dan prosedur dtatistika. (Penerjemah Sumantri B). Jakarta: PT Gramedia Pustaka Utama (1993) 
[10] Van Laack, H. D. L. R.L.J.M., C.H. Liu. Smith, M. O.: Characteristics of pale, soft, exudative broiler breast meat. Poult. Sci, vol. 79, pp. 1057-1061 (2000)

[11] Afrianti M, S.W. B., Dwiloka.: Total bakteri, $\mathrm{pH}$, dan kadar air daging ayam broiler setelah direndam dengan ekstrak daun senduduk (Melastoma malabathricum L.) Selama masa simpan, J. Pangan dan Gizi, vol. 4, no. 7, pp. 49-56 (2013)

[12] M. W. Buckle, K.A., R.A. Edwards, G.A. Fleet, Ilmu Pangan Terjemahan Hari P. dan Adiono. Jakarta: UI (1987)

[13] Soeparno.: Komposisi tubuh dan evaluasi daging dada sebagai pedoman penilaian kualitas produk ayam kampung jantan. Buletin Peternakan, vol. 16, pp. 6-14 (1992)

[14] Hadiwiyoto, S.: Kimia dan teknologi Daging Unggas. Pusat Antar Universitas Pangan dan Gizi. Universitas Gajah Mada, Yogyakarta (1992)

[15] Soeparno, R. Indratiningsih, S. Triatmojo, Dasar Teknologi Hasil Ternak. Yogyakarta: Fakultas Perternakan UGM (2001)

[16] Lawrie, R.: Ilmu Daging (5th ed.). Diterjemahkan oleh Parakkasi, A., dan Y. Amwila. Jakarta: UI Press (2003)

[17] R. A. M. Forrest, J.C., E.B. Aberle, H.B. Hedrick, M.D. Judge, Principles of Meat Science. San Fransisco: W.H. Freeman and Co (1975)

[18] F., Winarno.: Kimia Pangan dan Gizi. Jakarta: PT Gramedia Pustaka Utama (1997)

[19] Yanti, E. Hidayati, E.: Kualitas daging sapi dengan kemasan plastik PE (polyethylen) dan plastik PP (polypropylen) Di pasar arengka kota pekanbaru, J. Peternak., vol. 5, no. 1, pp. $22-27$ (2008)

[20] Honikel K, R. H.: Measurement of Wafer. Holding Capacity and Juiciness. London: Springer (1994)

[21] Lawrie, R.: Meat Science (3rd Ed.). The Avi Publishing Company, Inc. Westport. Connecticut, (1995)

[22] I. I. A. dan Y. W. Komariah.: Kualitas fisik dan mikrobia daging sapi yang ditambah jahe (Zinger officinale roecoe) pada konsentrasi dan lama penyimpanan yang berbeda. Media Peternak., vol. 28, no. 2, pp. 38-87 (2004)

[23] B. R. Simonsen,B.R.Hamm.: Meat a Food. Meat Sci. Milk Sci. Technol. Amsterdam (1988)

[24] Cannas, A.: Tannins. www.cornelluniversity.edu/Cornellpoisonplant, $:$ /ToxicAgents/Tannin/ html (2008)

[25] L. S. . and B. D. . Chan, W., Brown W.C, Meat.: Poultry and Game. Di dalam: Supplement to Mc Cane \& Widdowson's. The Composition of Foods. London: Published by The Royal society of Chemistry, Cambridge anf Ministry of Agriculture, Fisheries and Food.

[26] Soeparno.: Ilmu dan Teknologi Daging. Yogyakarta: UGM Press (2005)

[27] Fardiaz, S.: Mikrobiologi Pengolahan Pangan Lanjut. Bogor: Pusat Antar Universitas (1992) 